\title{
Author Correction: Small-molecule TFEB pathway agonists that ameliorate metabolic syndrome in mice and extend C. elegans lifespan
}

Chensu Wang ${ }^{1,2}$, Hanspeter Niederstrasser ${ }^{3}$, Peter M. Douglas ${ }^{4}$, Rueyling Lin ${ }^{4}$, Juan Jaramillo ${ }^{4}$, Yang Li ${ }^{1}$, Nathaniel W. Oswald ${ }^{3}$, Anwu Zhou ${ }^{3}$, Elizabeth A. McMillan ${ }^{2}$, Saurabh Mendiratta ${ }^{2}$, Zhaohui Wang ${ }^{1}$, Tian Zhao', Zhiqaing Lin', Min Luo', Gang Huang ${ }^{1}$, Rolf A. Brekken¹,5, Bruce A. Posner ${ }^{3}$, John B. MacMillan³, Jinming $\mathrm{Gao}^{1} \&$ Michael A. White ${ }^{2}$

Correction to: Nature Communications https://doi.org/10.1038/s41467-017-02332-3, published online on 22 December 2017.

The originally published version of this Article contained an error in the spelling of the author Nathaniel W. Oswald, which was incorrectly given as Nathaniel W. Olswald. This has now been corrected in both the PDF and HTML versions of the Article.

Published online: 21 May 2018

Open Access This article is licensed under a Creative Commons Attribution 4.0 International License, which permits use, sharing, adaptation, distribution and reproduction in any medium or format, as long as you give appropriate credit to the original author(s) and the source, provide a link to the Creative Commons license, and indicate if changes were made. The images or other third party material in this article are included in the article's Creative Commons license, unless indicated otherwise in a credit line to the material. If material is not included in the article's Creative Commons license and your intended use is not permitted by statutory regulation or exceeds the permitted use, you will need to obtain permission directly from the copyright holder. To view a copy of this license, visit http://creativecommons.org/licenses/by/4.0/.
}

(C) The Author(s) 2018

\footnotetext{
${ }^{1}$ Department of Pharmacology, Simmons Comprehensive Cancer Center, University of Texas Southwestern Medical Center, 5323 Harry Hines Boulevard, 75390 Dallas, TX, USA. ${ }^{2}$ Department of Cell Biology, University of Texas Southwestern Medical Center, 5323 Harry Hines Boulevard, 75390 Dallas, TX, USA. ${ }^{3}$ Department of Biochemistry, University of Texas Southwestern Medical Center, 5323 Harry Hines Boulevard, 75390 Dallas, TX, USA. ${ }^{4}$ Department of Molecular Biology, University of Texas Southwestern Medical Center, 5323 Harry Hines Boulevard, 75390 Dallas, TX, USA. ${ }^{5}$ Department of Surgery, University of Texas Southwestern Medical Center, 5323 Harry Hines Boulevard, 75390 Dallas, TX, USA. Correspondence and requests for materials should be addressed to J.G. (email: jinming.gao@utsouthwestern.edu) or to M.A.W. (email: michael.white@utsouthwestern.edu)
} 